4. Указ Президента РФ от 23 июля 2003 г. № 824 "О мерах по проведению административной реформы в 2003 - 2004 годах"

5. Аврутин Ю.Г. О методологии конституционно-правового исследования экономики // Известия высших учебных заведений. Правоведение: научно-теоретический журнал. 2008. № 1. С. 71-85

6. Раманкулов К.С. Власть и право в экономическом механизме: соотношение и функциональные связи // Известия высших учебных заведений. Правоведение: научно-теоретический журнал. 2006. № 5. С. 35-40

7. Лаптев В.В. Экономика и право (Теория и практика правового регулирования хозяйственных отношений). М.: Экономика, 1981. 216 с.

8. Малько А.В. Правовые средства как общетеоретическая проблема // Известия высших учебных заведений: Правоведение: научно-теоретический журнал. 1999. № 2. С. 4-11

9. Алексеев С.С. Правовые средства: постановка проблемы, понятие, классификация // Сов. государство и право. 1987. № 6. С. 12-19

10. Сорокин В.Д. Правовое регулирование: Предмет, метод, процесс (макроуровень). СПб.: Издательство «Юридический центр «Пресс», 2003. 661 с.

11. Лазарев В.В., Липень С.В. Теория государства и права: Учебник для вузов. М., 1996. 222 с.

12. Мамутов В.К. О комплексном изучении правового регулирования хозяйственных отношений // Правовое регулирование хозяйственных отношений. М., 1978. С. 8-30.

13. Теория государства и права: Учебник для вузов / Отв. ред. д.ю.н., проф. В.Д. Перевалов. - 3 -е изд. пе-рер. и доп. М.: Норма, 2007. 496 с.

14. Нукушева А., Ильясова Г., Кудрявцева Л., Попова Л., Шаяхметова З., Янтасова А. ТРАНСНАЦИОНАЛЬНЫЕ КОРПОРАЦИИ В МЕЖДУНАРОДНОМ ЧАСТНОМ ПРАВЕ: ЕСТЬ ЛИ У КАЗАХСТАНА И РОССИИ ПОТЕНЦИАЛ ДЛЯ ЛИДЕРСТВА? // Вопросы предпринимательства и устойчивого развития. 2020. Т. 8. № 1. С. 496-512.

15. Кудрявцева Л. В., Ставило С. П., Офисов В. В., Качур А. Н. НАПРАВЛЕНИЯ СОВЕРШЕНСТВОВАНИЯ ГРАЖДАНСКО-ПРАВОВЫХ ОТНОШЕНИЙ В СФЕРЕ ЗЕМЛЕПОЛЬЗОВАНИЯ // Средиземноморский журнал социальных наук. 2015. Т. 6. № 3 S3. C.115-122.

\title{
Бялт В.С., Чимаров С.Ю. \\ Правовые и организационные основы предотвращения и урегулирования конфликта интересов в органах внутренних дел
}

Санкт-Петербургский университет МВД России (Россия, Санкт-Петербург)

doi: $10.18411 / \mathrm{j}-06-2021-200$

\section{Аннотация}

В статье авторы исследуют вопросы, посвященные особенностям предотвращения и урегулирования конфликта интересов в органах внутренних дел с позиции противодействия коррупционным проявлениям среди личного состава органов внутренних дел. Анализируя нормативную правовую базу в указанной области, авторы формулируют и обосновывают ряд выводов касательно рассматриваемых вопросов.

Ключевые слова: конфликт интересов; противодействие коррупции; предотвращение и урегулирование конфликта интересов; органы внутренних дел.

\section{Abstract}

In the article, the authors explore issues related to the specifics of preventing and resolving conflicts of interest in the internal affairs bodies from the standpoint of combating corruption among the personnel of the internal affairs bodies. Analyzing the regulatory framework in this area, the authors formulate and justify a number of conclusions regarding the issues under consideration.

Keywords: conflict of interests; anti-corruption; prevention and resolution of conflicts of interests; internal affairs bodies. 
Проблема противодействия коррупции в системе государственной службы Российской Федерации признана руководством страны одной из наиболее важных, от решения которой во многом зависит успех проведения экономической, социальной, муниципальной, правоохранительной, административной и других реформ [5, с. 296]. В указанном смысле одним из важных аспектов совершенствования деятельности государственной службы является создание механизма разрешения конфликта интересов. Установление механизма разрешения конфликта интересов в системе государственной службы фактически вводит обязательную профилактику использования служебного положения в личных интересах, в том числе и по отношению к должностным лицам органов внутренних дел. Этот механизм делает возможной поэтапную, последовательную работу по устранению из повседневной практики органов публичной власти ситуаций, способствующих, стимулирующих, а иногда порождающих использование должностных полномочий в своих личных интересах, порождающих не только коррупцию, но и снижающих эффективность деятельности государственной службы [3, с. 45]. Сообразно с этим необходимо признать, что вопросы нормативного правового обеспечения предотвращения и урегулирования конфликта интересов в органах внутренних дел представляются весьма актуальными.

В законодательстве, регулирующим условия прохождения службы в органах внутренних дел, понятие конфликта интересов впервые было введено в статье 71 Федерального закона от 30 ноября 2011 года № 342-Ф3 «О службе в органах внутренних дел Российской Федерации и внесении изменений в отдельные законодательные акты Российской Федерации» (далее - Закон о службе). Ранее действующие правовые нормы всего лишь упоминали о конфликте интересов без разъяснения, данного понятия (статья 4 Положения о службе в органах внутренних дел Российской Федерации, утвержденного Постановлением Верховного Совета Российской Федерации 23 декабря 1992 года № 4202-1 - в настоящее время утратило силу в отношении сотрудников органов внутренних дел).

Согласно Закону о службе порядок предотвращения и урегулирования конфликта интересов устанавливается Президентом Российской Федерации [1]. В органах внутренних дел указанный документ конкретизируется ведомственным приказом [2].

Исследование обозначенных выше нормативных правовых актов, а также анализ сведений о служебной дисциплине в органах внутренних дел, свидетельствующий, что в 2020 году количество сотрудников, нарушавших служебную дисциплину, по сравнению с 2019 годом увеличилось на 4,2 \% [6, с. 45], позволяет нам сформулировать следующие предложения, которые, как нам представляется, позволят повысить эффективность работы комиссий по соблюдению требований к служебному поведению федеральных государственных служащих и урегулированию конфликта интересов в органах внутренних дел:

- периодически (не реже одного раза в три месяца) проводить видеоконференции на базе главного управления (управления) МВД России по субъекту Российской Федерации, посвященные вопросам предупреждения и урегулирования конфликта интересов;

- в рамках предупреждения и урегулирования конфликта интересов в органах внутренних дел руководителям всех уровней следует совершенствовать дисциплинарную практику; 
- в ходе занятий по правовой подготовке шире разъяснять законодательство Российской Федерации, регулирующее вопросы предупреждения и урегулирования конфликта интересов;

- повысить персональный спрос с руководителей всех уровней за непринятие мер по предотвращению и (или) урегулированию конфликта интересов [4, с. 44];

- устранить формализм при проведении заседаний комиссий, а также установить конкретную меру ответственности председателя и заместителя председателя комиссии за его проявления в процессе работы комиссии;

- расширить права комиссий в части, касающейся именно предупреждения конфликта интересов, а не только его урегулирования;

- разработать систему критериев оценки деятельности комиссий, позволяющих устанавливать результативность их работы; одним из главных подобных критериев, на наш взгляд, должен стать количественный показатель привлечения сотрудников органов внутренних дел к юридической ответственности за правонарушения, связанные с их личной заинтересованностью.

Таким образом, можно сформулировать следующие выводы:

1) вопросы анализа и совершенствования нормативного правового обеспечения урегулирования конфликта интересов в органах внутренних дел, безусловно, являются весьма актуальными, поскольку связаны с качеством выполнения сотрудниками органов внутренних дел своих служебных обязанностей и эффективностью функционирования всей системы МВД России;

2) необходимо реализовать на практике комплекс определенных мер, направленных на совершенствование деятельности комиссий по соблюдению требований к служебному поведению федеральных государственных служащих и урегулированию конфликта интересов в органах внутренних дел.

***

1. Указ Президента Российской Федерации от 1 июля 2010 года № 821 «О комиссиях по соблюдению требований к служебному поведению федеральных государственных служащих и урегулированию конфликта интересов» (в ред. от 19 сентября 2017 года) // СЗ РФ. 2010.№ 27. Ст. 3446; 2017. № 39. Ст. 5682.

2. Приказ МВД России от 31 июля 2012 года № 746 «О мерах по реализации отдельных положений Указа Президента Российской Федерации от 1 июля 2010 года № 821 «О комиссиях по соблюдению требований к служебному поведению федеральных государственных служащих и урегулированию конфликта интересов» в органах внутренних дел Российской Федерации» // Бюллетень нормативных актов федеральных органов исполнительной власти, 2012, 24 сентября, № 39 .

3. Анасова К. Б., Шутова Ю. А., Шутова А. А. Конфликт интересов в системе государственной службы // Актуальные проблемы современной науки, техники и образования. 2020. № 2. Т. 11. С. 44-48.

4. Комовкина Л. С. Предотвращение и урегулирование конфликта интересов в органах внутренних дел // Актуальные проблемы административного права и процесса. 2020. № 2. С. 42-45.

5. Малик Е. Н. Противодействие коррупции на государственной службе: поиск эффективных механизмом и приоритетов // Электронный сетевой политематический журнал «Научные труды КУБГТУ». 2020. № 3 . С. 295-301.

6. Состояние работы с кадрами органов внутренних дел Российской Федерации за 2020 год: Сборник аналитических и информационных материалов. - М.: ДГС МВД России, 2021 год. 